\title{
Penanganan delayed eruption karena impaksi gigi insisivus sentralis kiri dengan surgical exposure pada anak
}

\author{
Harun Achmad \\ Program Pendidikan Dokter Gigi Spesialis Ilmu Kedokteran Gigi Anak \\ Fakultas Kedokteran Gigi Universitas Padjadjaran \\ Bandung, Indonesia
}

\begin{abstract}
Delayed eruption is one of dental eruption deviation characterized by delay of dental eruption. Delayed eruption can be caused by local factor such as impacted tooth. This can be managed surgically and then orthodontically brought into the dental arch. An eleven years old girl came to the dental clinic specialist of FKG-UNPAD Bandung, with the chief complaint of having non-erupted upper left permanent central incisor, without retention of 61. Other 3 upper incisor, 11, 22, 12 have erupted normally. Panoramic examination showed impacted 11 in the alveolar bone with complete apex formation. Following the cephalometric and model analysis, the fixed orthodontic appliances were placed, followed by surgical exposure to open the impacted area then placed an orthodontic bracket with an attached chain to apply orthodontic forces on the tooth to aid its movement into the line of occlusion. After 6 months treatment, patient's esthetics and masticatory function were obtain, marked by normal position of 21 in the arch.
\end{abstract}

Keywords: delayed eruption, impacted tooth, surgical exposure

\begin{abstract}
ABSTRAK
Delayed eruption merupakan salah satu bentuk penyimpangan erupsi gigi yang ditandai dengan adanya keterlambatan erupsi gigi. Salah satu penyebabnya dapat berasal dari faktor lokal seperti impaksi gigi. Penanganan delayed eruption karena impaksi dapat dilakukan secara kombinasi bedah dan ortodontik dengan tujuan untuk memperbaiki posisi gigi dan hubungannya dengan lengkung rahang. Seorang anak perempuan berusia 11 tahun datang ke klinik spesialis FKG-UNPAD Bandung dengan keluhan gigi 21 tidak erupsi sehingga mengganggu pengunyahan dan tampilan. Pada foto panoramik terlihat gigi 21 masih tertanam dalam tulang alveolar dengan pembentukan apeks telah selesai tanpa adanya retensi gigi 61. Gigi 11, 22, 12 erupsi normal. Setelah analisis sefalometri dan analisis model, dilakukan pemasangan piranti ortodontik pada rahang atas yang diikuti tindakan bedah, kemudian pemasangan bracket dengan chain untuk mengaplikasikan daya ortodontik pada gigi dan menarik gigi tersebut ke posisi oklusi. Setelah enam bulan perawatan, fungsi pengunyahan dan penampilan dapat di peroleh karena gigi 21 telah berada pada posisi normal dalam lengkungnya.
\end{abstract}

Kata kunci : Delayed eruption, impaksi gigi, surgical exposure

Koresponden: Harun Achmad, Program Pendidikan Dokter Gigi Spesialis Ilmu Kedokteran Gigi Anak Fakultas Kedokteran Gigi Universitas Padjadjaran, Bandung, Indonesia 


\section{PENDAHULUAN}

Prevalensi maloklusi di Indonesia masih sangat tinggi, yaitu sekitar $80 \%$ dari jumlah penduduk. Hal tersebut menyebabkan antisipasi perkembangan angka kejadian maloklusi, khususnya maloklusi pada anak diperlukan upaya penanggulangan secara dini, khususnya pengetahuan secara lebih luas mengenai penyebab terjadinya maloklusi tersebut.

Terjadinya maloklusi dapat disebabkan oleh beberapa faktor, seperti faktor genetik, fungsi, trauma, serta kebiasaan buruk. Adapun upaya pencegahan dini dan penanggulangan maloklusi pada anak dapat dilakukan dengan interceptive orthodontics, yaitu suatu perawatan maloklusi anak pada masa proses tumbuh kembang sebelum oklusi gigi mencapai sempurna. Tujuan perawatan interceptive orthodontics adalah mengurangi serta memperbaiki faktor penyebab terjadinya maloklusi, yang jika tidak dilakukan akan terjadi kondisi lebih buruk pada masa yang akan datang terhadap perkembangan oklusi dan struktur jaringan mulut lainnya. ${ }^{1,2}$

Salah satu faktor yang dapat menghambat kelancaran perawatan interceptive orthodontics yaitu adanya gigi yang tertanam dalam tulang rahang atau gigi yang perlu dilakukan tindakan bedah minor terlebih dahulu karena menghalangi perawatan yang akan dilakukan selanjutnya. ${ }^{1,2}$

Erupsi gigi merupakan suatu proses perubahan posisi gigi yang diawali dengan pertumbuhan dalam tulang rahang melalui beberapa tahap hingga mencapai posisi fungsional dalam rongga mulut. Proses ini dapat berjalan secara normal dalam arti sesuai dengan waktu erupsi masing-masing gigi, ataupun mengalami penyimpangan. Salah satu bentuk penyimpangan ini adalah delayed eruption yang ditandai dengan keterlambatan erupsi gigi. Seorang anak dikatakan mengalami keterlambatan erupsi apabila terdapat perbedaan sekitar 2 tahun dari rerata waktu erupsi normal. Faktor-faktor yang menyebabkan terjadinya keterlambatan erupsi dapat berasal dari faktor lokal antara lain impaksi gigi. ${ }^{1-3}$

Perawatan bedah terdiri dari pembukaan daerah impaksi dan penempatan suatu piranti yang melekat pada gigi. Bila memungkinkan pembukaan sebaiknya lengkap sampai ke attached gingiva untuk mendapatkan kondisi periodontal yang lebih baik setelah perawatan. Hal ini menimbulkan sedikit masalah pada gigi yang berada lebih ke palatal. Impaksi yang berada lebih ke labial memerlukan pembukaan sampai ke jaringan lunak, namun kemungkinan besar dapat menimbulkan penyakit periodontal. Kecenderungan ini dapat dikurangi dengan menggunakan flap reposisi apikal, pencangkokan reposisi lateral, atau pencangkokan free gingival margin. 4,5

Jika aplikasi daya dibutuhkan sebagai penuntun jalan keluar erupsi gigi impaksi, maka harus dibuat suatu piranti yang melekat pada gigi. Banyak metode pelekatan gigi yang dapat digunakan seperti kawat pengikat melingkar, direct bond bracket, band ortodontik, mahkota logam atau onlay, dan pin berulir. ${ }^{4-7}$

Dalam laporan kasus ini akan dibahas mengenai upaya pencegahan dan penanggulangan dini kemungkinan terjadinya maloklusi, dengan piranti cekat yang melibatkan tindakan bedah minor. Akan dibahas mengenai tindakan pembedahan dan pemasangan button pada gigi 21 yang mengalami impaksi, yang dikombinasikan dengan pemakaian piranti cekat ortodontik.

\section{LAPORAN KASUS}

Seorang anak perempuan yang berusia 12 tahun dengan inisial $\mathrm{N}$, datang ke Klinik Ilmu Kedokteran Gigi Anak Fakultas Kedokteran Gigi Universitas Padjajaran dengan keluhan utama gigi 
21 hingga saat itu belum erupsi tanpa adanya retensi gigi 61. Perkembangan fisik anak tersebut sesuai dengan perkembangan usia. Pemeriksaan ekstra oral menunjukkan bahwa pasien memiliki profil wajah datar dengan tipe wajah sempit seperti terlihat pada gambar 1 . Selain itu, tidak terdapat kelainan pada sendi temporomandibula, bibir, dan relasi bibir.

Pemeriksaan intra oral memperlihatkan maloklusi kelas I Angle akibat gigi 21 tidak erupsi. Pemeriksaan palpasi pada daerah labial regio gigi 21 teraba adanya tonjolan yang menandakan adanya benih gigi (gambar 2).

Dari foto panoramik, seperti tampak pada Gambar 2, menunjukkan gigi 21 berada dalam tulang alveolar dengan posisi vertikal dan sedikit berotasi ke mesial. Pembentukan apeks gigi 21 telah selesai sehingga rencana perawatan dilakukan surgical exposure dan traksi ortodontik.

\section{Tata laksana kasus}

Sebelum pembedahan, dilakukan pemasangan piranti ortodontik cekat untuk alignment dan leveling gigi-gigi (gambar 3A). Satu bulan setelah alignment dan leveling, dilakukan overcorrection celah antara gigi 11 dan 22 dengan menggunakan pegas ulir kompresi untuk menyediakan celah untuk memudahkan erupsi gigi 21 (gambar 3B).
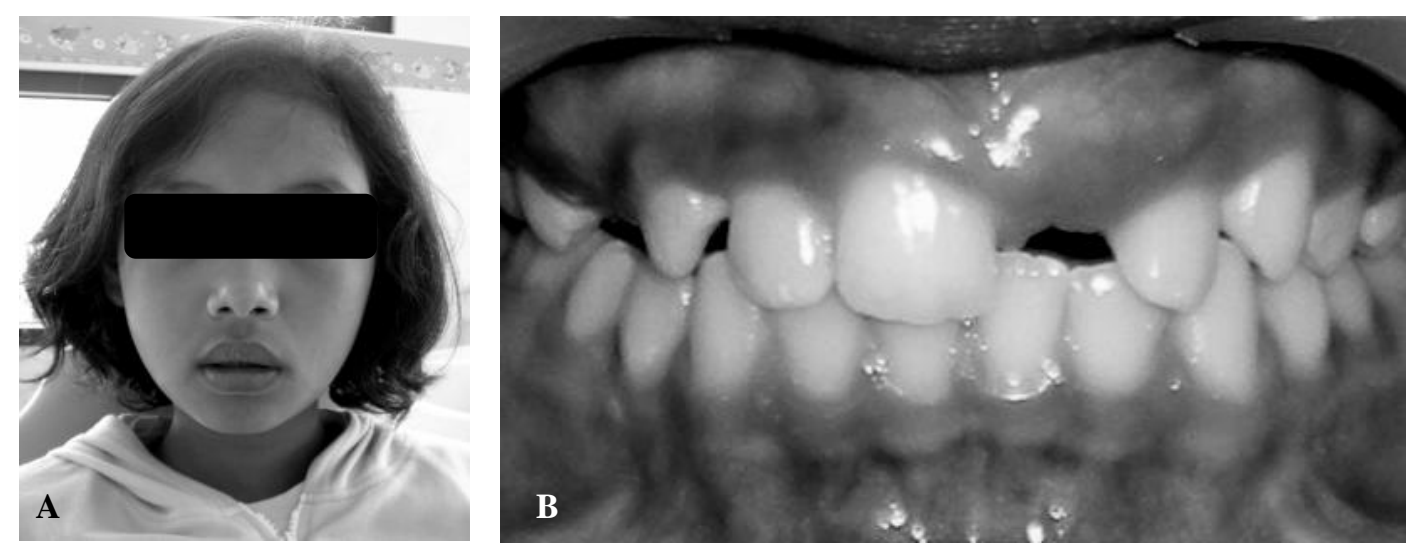

Gambar 1. (A) Foto wajah pasien sebelum perawatan, dan (B) Foto intra oral awal, terlihat tonjolan pada gingival regio labial gigi 21 .

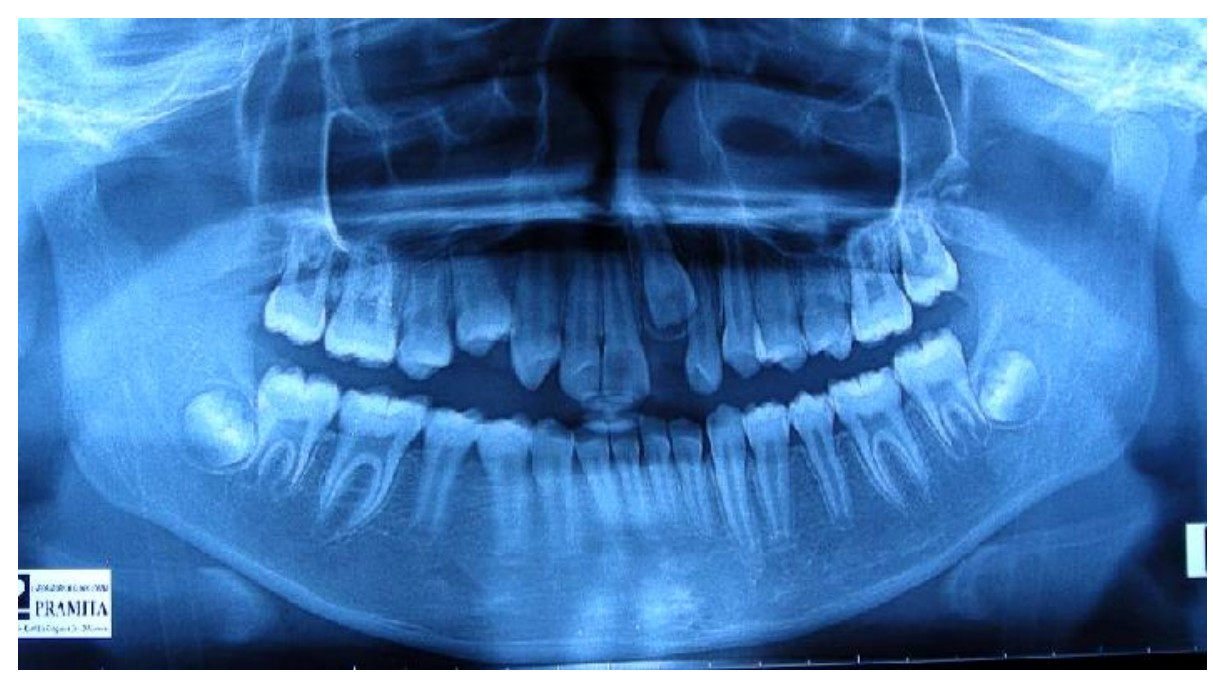

Gambar 2. Foto panoramik. 
Pembedahan dilakukan setelah ruangan bagi gigi 21 tersedia. Surgical exposure dilaksanakan di bawah pengaruh anestesi lokal dan dilakukan dengan membuang jaringan gingiva pada regio labial 21 sedemikian sehingga memungkinkan penempatan button. Penempatan button dan traksi ortodontik dilakukan pada saat pembedahan. Kontrol dilakukan seminggu sekali (gambar 4).

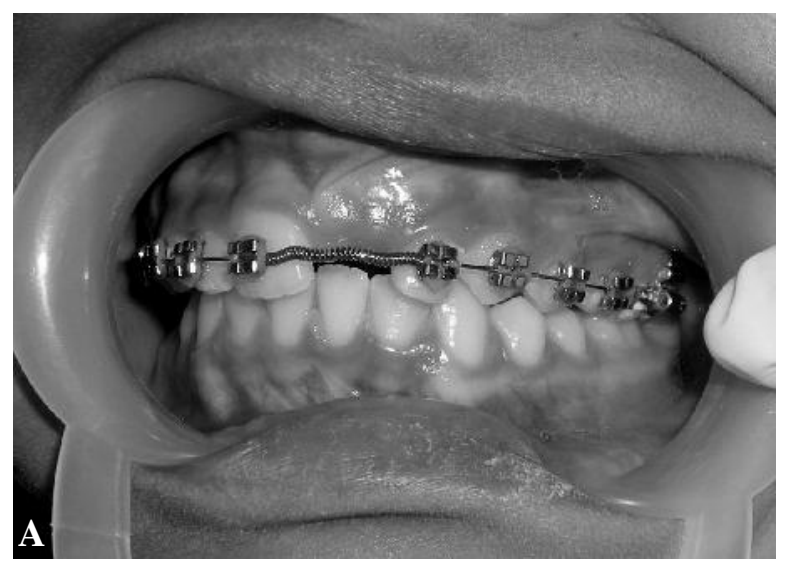

Gambar 3. Pemasangan piranti ortodontik cekat untuk alignment dan leveling (A), dan overcorrection dengan pegas ulir kompresi antara gigi 11 dan 22 (B).
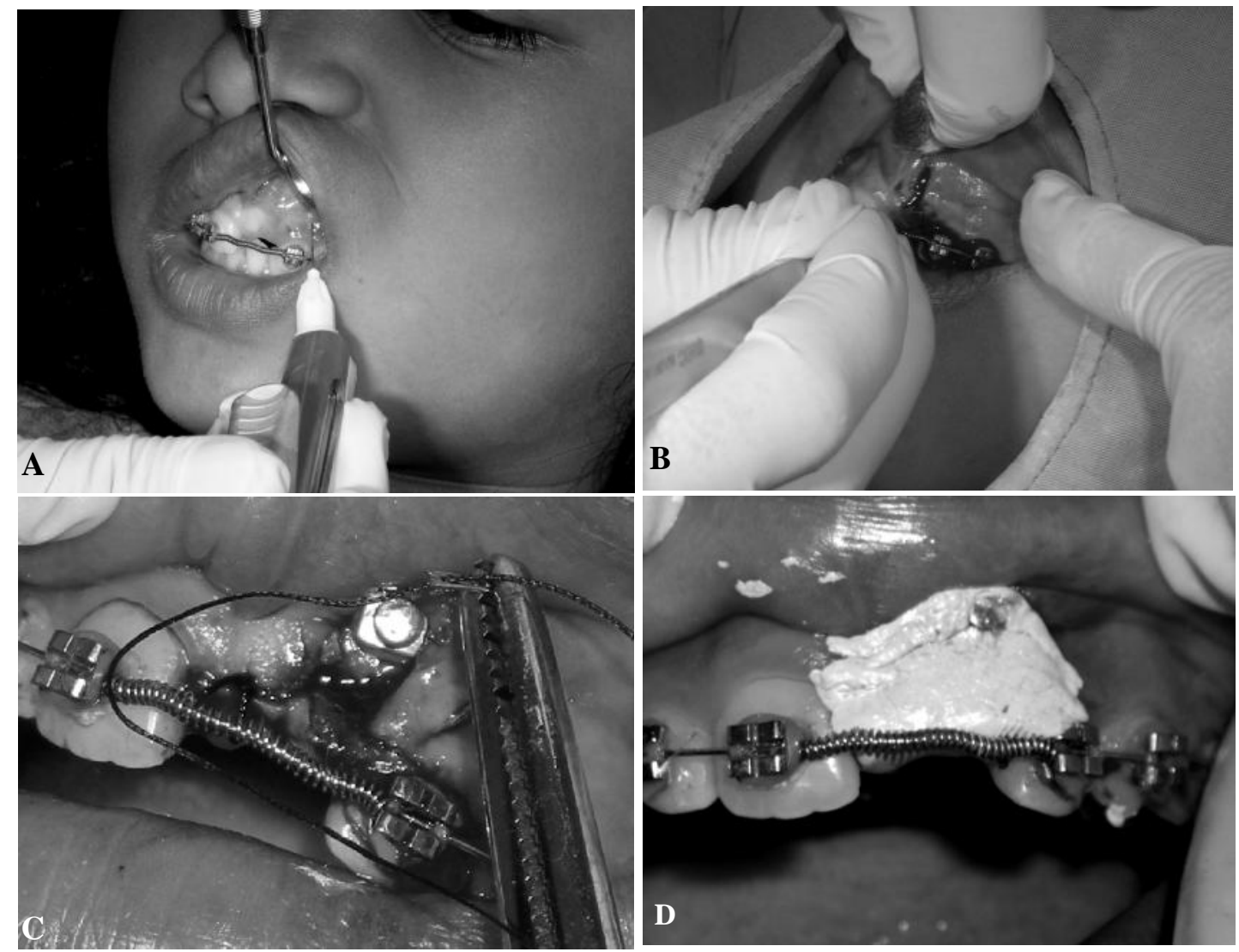

Gambar 4. Tahapan surgical exposure. Anestesi lokal (A), insisi jaringan gingival (B), penjahitan dan pemasangan button (C), dan pemasangan periodontal pack (D). 


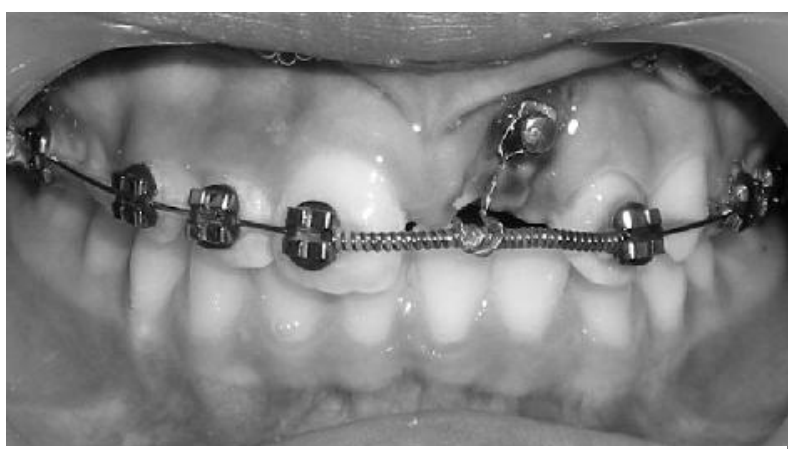

Gambar 5. Foto intra oral setelah pemasangan button pada gigi 21 dan traksi ortodontik.

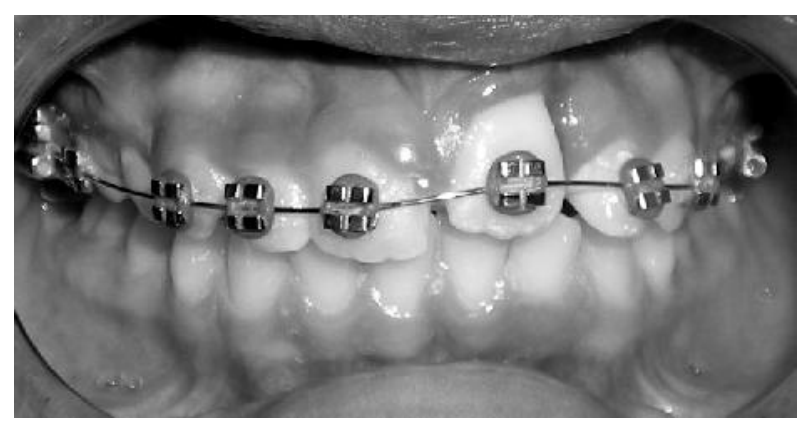

Gambar 6. Dua bulan setelah pembedahan.

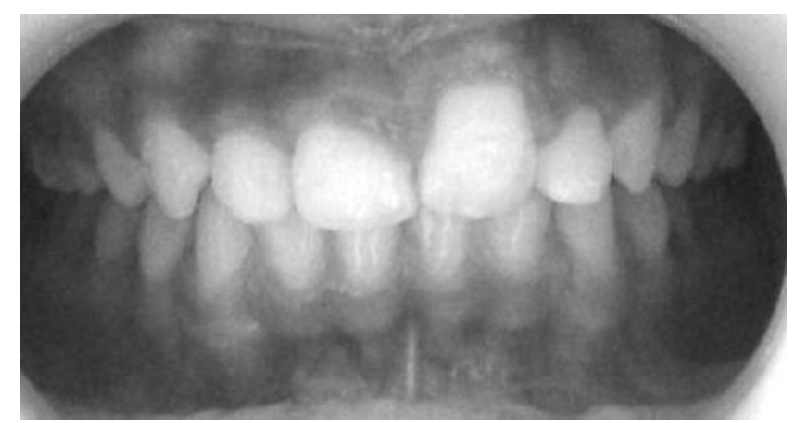

Gambar 7. Enam bulan setelah pembedahan.

\section{PEMBAHASAN}

Minor surgery dalam kedokteran gigi anak adalah suatu tindakan yang melibatkan adanya operasi kecil yang sesuai dengan kompetensi ilmu kedokteran gigi anak. Tindakan ini dapat berupa pencabutan gigi, operasi frenulum, operasi pencabutan gigi yang mengalami impaksi, kuretase, insisi, serta operasi untuk melakukan pemunculan gigi yang tertanam seperti kasus pada makalah ini. ${ }^{8-10}$
Impaksi adalah sesuatu hambatan yang mencegah erupsi gigi karena adanya penghalang secara fisik pada jalannya erupsi. Gigi yang paling sering mengalami impaksi adalah molar ketiga rahang bawah, disusul dengan kaninus rahang atas, molar ketiga rahang atas, premolar kedua rahang atas dan bawah, dan terakhir insisivus sentralis rahang atas. ${ }^{9-11}$

Etiologi dari impaksi bermacam-macam, diantaranya kekurangan ruang, kista, supernumerary teeth, retensi gigi sulung, infeksi, trauma, anomali, dan kondisi sistemik. Penatalaksanaan gigi yang mengalami impaksi secara umum adalah meniadakan faktor etiologi, yaitu dengan pengangkatan obstruksi, seperti supernumerary teeth dan odontoma, surgical exposure dan traksi ortodontik, ataupun gingivektomi. $^{10,11}$

Masalah dalam penatalaksanaan gigi impaksi dibagi ke dalam 3 katagori, yaitu surgical exposure, perlekatan pada gigi, dan mekanik ortodontik untuk mengarahkan gigi ke dalam lengkung. ${ }^{5}$ Diagnosis impaksi gigi anterior memerlukan riwayat keseluruhan dan pemeriksaan klinis. Anamnesis diperlukan untuk mendapatkan keterangan mengenai riwayat trauma gigi sejak masa awal kanak-kanak. Suatu luka traumatik terus menerus pada gigi sulung dapat mengganggu perkembangan gigi permanen, karena dapat menyebabkan perubahan struktural seperti dilaserasi dan malformasi akar. Perubahan ini dapat menyebabkan gigi tersebut tidak erupsi. ${ }^{10,11}$

Palpasi pada daerah palatal dan vestibular merupakan pemeriksaan tambahan dalam diagnosis dan penentuan lokasi impaksi. Diagnosis suatu impaksi gigi bervariasi dan lokasinya ditentukan dari evaluasi radiografi. Foto oklusal memberikan gambaran yang terbaik dari 
impaksi gigi dan akan membantu menentukan posisi anteroposterior dan lateral., ${ }^{4,10,11}$

Keterlibatan prosedur pembedahan pada kasus impaksi, tergantung beratnya impaksi. Hal ini dapat dikategorikan pilihan perawatan berdasarkan jenis maloklusi, banyaknya deformasi gigi, dan lokasi impaksi gigi anterior. Hal tersebut dapat dijelaskan sebagai berikut, jika ada ruang dan gigi impaksi tidak tertanam jauh di dalam mukosa, maka pengangkatan penyebab impaksi adalah merupakan jalan terbaik. Jika gigi impaksi mempunyai malformasi nyata dan terdapat maloklusi yang berat, maka indikasi untuk dilakukan pencabutan. Jika gigi impaksi mempunyai bentuk normal atau malformasi ringan, dan maloklusi hanya disebabkan oleh gigi yang impaksi serta gigi anterior di sekitarnya, maka dapat dilakukan perawatan bedah., ${ }^{4,5,11}$

Gigi yang mengalami keterlambatan erupsi akibat impaksi pada pasien remaja biasanya dapat dibawa ke posisi oklusi dengan traksi ortodontik setelah sebelumnya jaringan yang menutupi gigi impaksi tersebut dibuka secara pembedahan. ${ }^{5,7,11}$

Dalam merencanakan perawatan untuk impaksi gigi permanen, tiga prinsip yang harus diikuti. Pertama adalah prognosis harus didasarkan pada luasnya displacement dan trauma bedah yang diperlukan untuk exposure. Makin besar displacement dan makin besar trauma, makin buruk prognosis. Ekstraksi gigi impaksi dan penutupan ruangan secara ortodontik atau penggantian gigi secara prostodontik merupakan perawatan yang lebih baik dari pada usaha menarik gigi impaksi tersebut ke oklusi. Kedua, saat surgical exposure, jaringan yang menutupi erupsi gigi harus dibuang sehingga gigi dapat ditarik. Sedangkan ketiga dalah ruangan harus tersedia bagi gigi yang akan ditarik sebelum pembedahan dilakukan. $5,7,10,11$
Dalam kasus ini, surgical exposure dan traksi ortodontik dilakukan dengan pertimbangan pembentukan apeks yang telah selesai, sementara erupsi spontan dari gigi setelah pembedahan tidak dapat diharapkan. Biasanya, gigi akan erupsi setelah hal yang menghalangi erupsinya dihilangkan dengan pembedahan, namun hal ini tidak dapat terjadi setelah pembentukan akar selesai.

Prognosis pasien pada kasus ini adalah baik, karena gigi yang mengalami impaksi berada dalam posisi vertikal dan hanya ditutupi oleh jaringan fibrosa yang mengeras sehingga trauma bedah dapat diminimalkan. Hasil foto periapikal menunjukkan bahwa ruangan yang tersedia cukup bagi erupsi gigi, namun karena gigi dalam posisi sedikit berotasi ke mesial maka dilakukan overcorrection ruangan antara gigi 11 dan gigi 22 untuk mengantisipasi kekurangan ruangan pada saat alignment dan leveling setelah gigi mencapai oklusi. Tiga bulan setelah pembedahan, gigi-gigi telah menempati posisi yang ideal dan memasuki tahap penyelesaian (gambar 6). Dalam jangka waktu 4 hingga 6 bulan, piranti ortodontik cekat ini kemudian dilepas dan diganti dengan piranti retensi lepasan (gambar 7).

\section{SIMPULAN}

Perawatan delayed eruption karena impaksi gigi anterior dapat dilakukan dengan metode bedah dan ortodontik. Diagnosis yang tepat dan benar merupakan hal yang penting untuk menentukan waktu perawatan dan kemungkinan intervensi bedah. Perkembangan perawatan dan rencana mekanik harus didasarkan pada analisis yang tepat dari keadaan klinis dan identifikasi sistem daya yang tepat untuk mencapai pergerakan gigi yang diharapkan. 


\section{DAFTAR PUSTAKA}

1. Koch G. Pediatric dentistry a clinical approach. Copenhagen: Munksgaard; 2001. p.325.

2. Rakosi T. Color atlas of dental medicine: orthodontic diagnosis. New York: Thieme Medical Publisher Inc.; 1993. p. 57-85.

3. Blinkhorn AS. Practical treatment planning for the paedodontics patient. Chicago: Quintessence Publishing Co. Inc.; 1992. p. 1722.

4. Douglas DE. J Dent Child 1989;

5. Proffit WR. Contemporary orthodontics. Missouri: Mosby International Inc.; 2000. p. 233, 538-42.

6. Bishara SE. Textbook of orthodontics.
Philadelphia: WB. Saunders Company; 2001. p. 546-57.

7. Nanda R. Biomechanics in clinical orthodontics. Philadelphia: W.B. Saunders Company; 1997. p. 99-101.

8. Welbury RR. Paediatric dentistry. New York: Oxford University Press; 2000. p. 294, 324-5.

9. Cameron A, Widmer R. Handbook of pediatric dentistry. Philadelphia: Mosby International Limited; 1998. p. 227.

10.Pinkham JR. Pediatric dentistry. $4^{\text {th }}$ ed. Philadelphia: WB Saunders Co; 2005. p.616-9.

11.Bijoor R, Kavita K. Contemporer space maintenance for the pediatric patient. New York State Dent J 2005; 71-8. 